DOI: $10.21554 / \mathrm{hrr} .041907$

\title{
PROSOCIAL BEHAVIOR FROM THE ASPECT OF THE STRUCTURE OF LEISURE TIME
}

\section{Edin Muftić ${ }^{1}$ \\ Adela Jahić \\ Ranko Kovačević}

Faculty of Education and Rehabilitation, University of Tuzla, Bosnia and Herzegovina
Original scientific paper

Received: $2019 / 12 / 18$

Accepted: 2019/2/16

\begin{abstract}
The aim of the research is to determine the characteristics of the prosocial behavior of primary and high school students in terms of the structure of leisure time. The sample of respondents consists of 230 students of the final grades of primary and high schools, both genders, aged 14-19. The research was conducted in the area of Tuzla during the school year 2017/2018. years. The survey used the measuring instrument "Scale of self-assessment of juvenility behavior YSR". Mann Whitney $U$ test was used for statistical analysis of data. When analyzing the prosocial behavior of primary and high school students in terms of the structure of leisure time, statistically significant differences at the level of $p \leq 0,05$ were established in such a way that students with structured leisure time compared to students whose leisure time is not structured more often: are fairly honest, they do things better than most children, they can be pretty friendly, they are skillful with their hands, they fight for their rights, enjoy being with other people, they like to make others laugh, they like to help others.
\end{abstract}

Keywords: leisure time, children and juvenility, prosocial behavior

\section{INTRODUCTION}

The issue of choosing the content that young people fulfill their leisure time with is one of the keys to assessing the quality of their everyday life, but also to understand their needs, as well as the potential to evolve in the future, with the remark that leisure time is often associated with risky behaviors (Žiga et al., 2015). According to Badrić and associates (2011), in order to ensure that children's leisure time is well organized, the question of the structure of the time in one day should be posed, with a view to the fact that in everyday life the simplest division of the notion of time, working time or time, which is called the "nonfree time", as well as for leisure or time remaining to the individual available after completing his duties. In pedagogical literature, the term "leisure time" denotes "the time that an individual fills and shapes according to his own desires, without any obligation and necessity“. It is a part of the life of every person who exists every day and in every environment, but is different in view of the age, gender, interest, place of residence, development of the environment, degree of interest, goals of the social order and its possibilities.

\section{${ }^{1}$ Correspodence to:}

Edin Muftic, PhD, Faculty of Education and Rehabilitation, University of Tuzla, Bosnia and Herzegovina

Univerzitetska 1, 75000 Tuzla, Bosnia and Herzegovina

Phone:+38761 403352

E-mail: edin.muftic@untz.ba 
Leisure is an integral part of man's activity, a time beyond professional, family and social obligations, in which an individual chooses, at his will, the forms and contents of rest, recreation and creativity "(Pedagogical Encyclopedia II, 1989, 353). Already by its essential characteristics and conditions provided by leisure time, it enables the realization of the human need for self-activity, as well as its desire to freely choose the social environment, activity and the media of its expression, communication, knowledge, and, by changing the environment, the contents and means of expression, to try out its creative potential, its identity (Nola, 1990). In their leisure time, young people most often choose activities of a social nature, such as going out and socializing with friends, while far less interest they show for cultural and educational activities. (Fitzgerald et al, 1995; Ilishin, et al., 2001; Ilishin, 2002; Vrkić Dimić 2005, 2007, according to Pehlic, 2014). The fun of young people, according to Pehlic (2014), is to fulfill the time available to them after normal work, school obligations, and entertainment activities and activities require little or no engagement. Mlinarevic (2004) states that if an adolescent is connected with peers who have positive norms and values, he will accept them himself, and if they have deviant norms, there is (Oetting, Donnermeyer, 1998), a great chance that he will accept the same. Adolescents do not attach to a random group, they choose them by similarity or importance.

Prosocial behavior involves social behavior that is basically charity, helping others, meeting their needs or removing difficulties. In the broadest sense, prosocial behavior is defined as a willing intentional behavior that has positive consequences for other people. Prosocial behavior includes benevolence, kindness, material help and moral support, empathy and altruism (Eisenberg and Miller, 1987, according to Raboteg-Saric, 1993). The motivational basis of prosocial behavior has been observed through many studies. On the basis of them, several models have been identified that interpret the connection between the situation conditions and the psychological processes that jointly condition the occurrence of prosocial behavior. Depending on which processes are given greater importance, normative, cognitive and emotional models are distinguished (Raboteg-Šarić, 1993).
Every activity in leisure time contains its developmental, self-activating and primary preventive role. If educational activity is achieved in leisure time, the results of upbringing for leisure time are achieved and leisure time activities become a necessity for self-actualization of the personality of young people, then leisure activities fulfill both of these roles.

Speaking about the importance of leisure time, Pehlic (2015) states the following: "Leisure time is a time in which individuals can live in harmony with their individual nature, in which they can affirm and further develop their own qualities. It is an important opportunity for rest, leisure, distraction from everyday worries and burdens and is an important factor in the "liberation" of young people. Unless efforts are made to make leisure time constructive, it can easily be destructive in the process of individual youth development. "The attitudes and behavior of young people in the adolescence period, according to Meskic - Blazevic (2007), are strongly influenced by friends and peer groups, with the influence and pressure of the peer group stronger that the person is more precarious and more inclined to social conformation. The author also emphasizes that one of the most important risk factors for the emergence and development of behavioral disorders, namely socializing with persons of delinquent behavior, and in the environment of such persons, regular negative proofs and the struggle for hierarchical prestige lead to deeper social decline.

\section{The aim of research and hypothesis}

The aim of the research is to determine the characteristics of the prosocial behavior of primary and high school students in terms of the structure of leisure time. The paper assumes that students who have structured leisure time are more prosocially oriented.

\section{METHODS}

The sample of respondents consists of 230 pupils of the final grades of primary and high schools, both genders, aged 14-19. The research was conducted in the area of Tuzla.

Table 1. Structure of the sample of respondents from the aspect of gender and school age

\begin{tabular}{|c|c|c|c|c|c|c|}
\hline \multirow{3}{*}{ Gender of respondents - pupils } & \multicolumn{4}{|c|}{ School age of students - final grades } & \multirow{2}{*}{\multicolumn{2}{|c|}{ Total respondents }} \\
\hline & \multicolumn{2}{|c|}{ Primary school } & \multicolumn{2}{|c|}{ High school } & & \\
\hline & $\mathrm{N}$ & $\%$ & $\mathrm{~N}$ & $\%$ & $\mathrm{~N}$ & $\%$ \\
\hline Male & 32 & 13.9 & 52 & 22.6 & 84 & 36.5 \\
\hline Female & 46 & 20.0 & 100 & 43.5 & 146 & 63.5 \\
\hline Total respondents & 78 & 33.9 & 152 & 66.1 & 230 & 100.0 \\
\hline
\end{tabular}


The sample of respondents includes students in the final grades of primary and high schools, and the structure consists of $78(33.9 \%)$ students in the final grades of the primary school and $152(66.1 \%)$ of students in the final grades of high school, while from the aspect of the gender of the respondents, the structure implies 84 (36.5\%) male students and 146 (63.5\%) female students in the final grades. During the research, a questionnaire was used that was specifically designed for the purposes of this research in the part relating to leisure time, and

\section{RESULTS AND DISCUSSION}

Table 2. Frequency of response to the question of satisfaction with the way of spending leisure time

\begin{tabular}{lcc}
\hline \multicolumn{1}{c}{ Answer Options } & \multicolumn{2}{c}{ Variable } \\
\cline { 2 - 3 } & $\mathrm{N}$ & \multicolumn{2}{c}{ Satisfaction with the way of spending leisure time } \\
\hline Completely unsatisfied & $\%$ & 3.9 \\
\hline Unsatisfied & $\mathrm{N}$ & 14 \\
& $\%$ & 6.1 \\
\hline Neither satisfied nor unsatisfied & $\mathrm{N}$ & 101 \\
& $\%$ & 43.9 \\
\hline satisfied & $\mathrm{N}$ & 73 \\
& $\%$ & 31.7 \\
\hline Completely satisfied & $\mathrm{N}$ & 33 \\
& $\%$ & 14.3 \\
\hline Total respondents & $\mathrm{N}$ & 230 \\
& $\%$ & 100.0 \\
\hline
\end{tabular}

The student satisfaction with the way of spending leisure time is the following: 101 (43.9\%) of students finishing primary and high school is neither satisfied nor unsatisfied, 73 (31.7\%) of students are satisfied with the way of spending leisure time and $33(14.3 \%)$ of students express complete satisfaction, while 14 (6.1\%) of students expressed complete satisfaction and $9(3.9 \%)$ of students expressed complete dissatisfaction with the

way of spending leisure time.

Two surveys conducted in 2005 in Slavonia on a sample of 455 high school students and in 2006 in Zadar on a sample of 1000 high school students show that high school students in Slavonia are satisfied with the spending of leisure time $(54.0 \%)$ compared to high school students in Zadar (44.0\%) (Mlinarević et al., 2007).

Table 3. Frequency of the answer to the question about the decision on the way of spending leisure time

\begin{tabular}{|c|c|c|}
\hline Answer Options & \multicolumn{2}{|c|}{ Variable } \\
\hline Made the decision myself & $\mathrm{N}$ & 179 \\
\hline & $\%$ & 74.0 \\
\hline \multirow[t]{2}{*}{ Made the decision with the help of family } & $\mathrm{N}$ & 30 \\
\hline & $\%$ & 12.4 \\
\hline \multirow[t]{2}{*}{ Made the decision with the help of school and teachers } & $\mathrm{N}$ & 16 \\
\hline & $\%$ & 6.6 \\
\hline \multirow{2}{*}{$\begin{array}{l}\text { Made the decision with the help of a club or association of which } \\
\text { I am a member }\end{array}$} & $\mathrm{N}$ & 11 \\
\hline & $\%$ & 4.5 \\
\hline \multirow[t]{2}{*}{ Made the decision with the help of someone else } & $\mathrm{N}$ & 6 \\
\hline & $\%$ & 2.5 \\
\hline \multirow[t]{2}{*}{ Total answers } & $\mathrm{N}$ & 242 \\
\hline & $\%$ & 100.0 \\
\hline
\end{tabular}


The decision on the way of leisure time is given by the students of the final grades of primary and high school independently (alone), which is confirmed by 179 (74.0\%) answers, followed by decisions made with the help of family - $30(12.4 \%)$ answers, followed by $16(6.6 \%)$ answers referring to the help of school and teachers, while $11(4.5 \%)$ student responses are the help of a club or association whose members they are, $6(2.5 \%)$ answers to the question about making a decision on how to spend leisure time is related to the help of someone else, where $5(2.1 \%)$ responses refer to the help of friends, and $1(.4 \%)$ answer refers to dependence on obligations and time.

According to Tomić and Hasanović (2007), a survey con- ducted on a sample of 442 primary school students in Brčko, Žepče, Živinice, Kalesija and Gračanica shows that the majority of respondents, that is, $72.4 \%$ choose the activities in their leisure time independently, and from the socialization agents which direct them to the proper organization of leisure time, the family has the strongest influence on them, that is, the parents $15.8 \%$.

The same authors also state that the results of the research on the sample of 640 high school students in our country show that most of the respondents $(73.4 \%)$ spend leisure time freely and their own choice, and that the influence of the family $(6.4 \%)$ and the school $(5.6 \%)$ is insignificant on the spending of leisure time of high school students.

Table 4. Frequency of the answer to the question about the organization (structure) of leisure time

\begin{tabular}{llc}
\hline Answer Options & \multicolumn{2}{c}{ Variable } \\
\cline { 2 - 3 } & \multicolumn{2}{c}{ Organization (structure) of leisure time } \\
\hline Yes & $\mathrm{N}$ & 103 \\
& $\%$ & 44.8 \\
\hline No & $\mathrm{N}$ & 127 \\
& $\%$ & 55.2 \\
\hline Total respondents & $\mathrm{N}$ & 230 \\
& $\%$ & 100.0 \\
\hline
\end{tabular}

The organization or structure of leisure time is present in $103(44.8 \%)$ students in the final grades of primary and high schools, while 127 (55.2\%) of students think that their leisure time is not organized.

Based on the results of the research carried out in 2000 in Croatia on a sample of 1000 students, aged
11 to 15 , according to Ilishin (2013), a quarter of children are not occupied with any extracurricular activities. A survey conducted in 2004 in Pula, referring to 1397 primary school students, found that $68.1 \%$ of students were involved in some organized extracurricular activity (Marković, Arsić, 2005).

Table 5. The credit for creating leisure time activities for young people

\begin{tabular}{llc}
\hline The credit for creating leisure time activities for young people & $\begin{array}{l}\text { Ranking by relevance - least important (rank 8) / } \\
\text { most important }\end{array}$ \\
\hline Every young person for itself & 1 \\
Parents & 2 \\
School & 3 \\
Friends & 4 \\
Youth associations & 5 \\
Representatives of the local community & 6 \\
Media & 7 \\
Someone else & 8 \\
\hline
\end{tabular}

Primary and high school students of final grades were tasked to rank the importance of taking credit for designing leisure activities of young people with the possibility of correspondence with someone in their opinion, and the results show that students are aware that they are primarily responsible for conducting their leisure time, so the option "every young person for itself" is ranked on the first place in the highest number, then, in their opinion, on the second position of significance, there is the option "parents", on the third "school" and on the fourth position "friends". The remaining four positions relate to the options "youth associations", "representatives of the local community", the "media", and as an opportunity to correspond to another student, the following answers are given: brother / sister, relatives, neighbors, boyfriend / girlfriend, trainer, acquaintances, community members and someone older. 
Table 6. Mann Whitney test for prosocial behavior from the aspect of leisure time structure

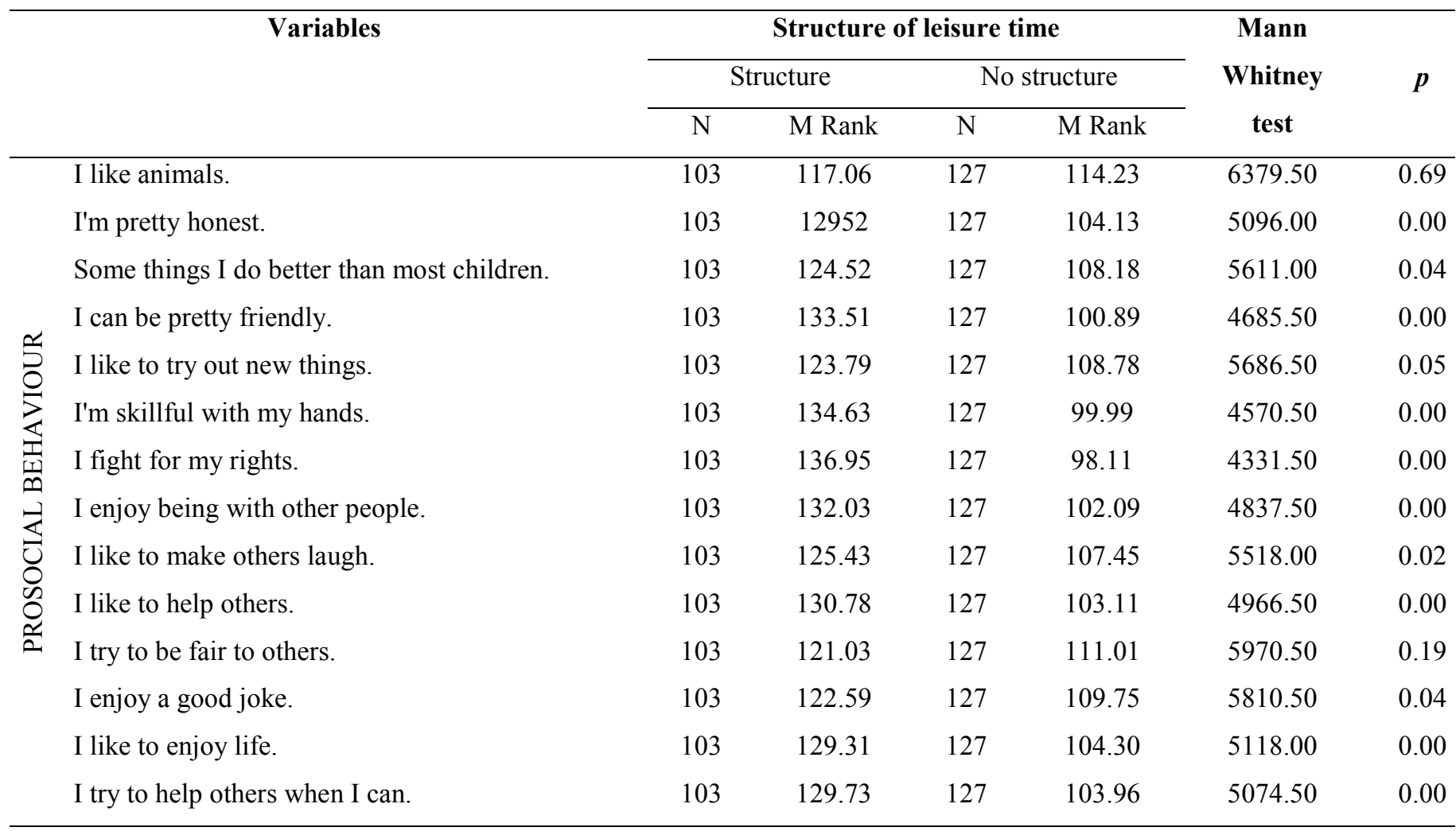

When analyzing the prosocial behavior of primary and high school students of final grades in terms of the structure of leisure time, statistically significant differences at the level of $\mathrm{p} \leq .05$ were established in such a way that students with structured leisure time performance compared to students whose leisure time is not structured more often :

- are pretty honest

- do some things better than most children

- can be pretty friendly

- are skillful with their hands

- fight for their rights

- enjoy being with other people

- like to make others laugh

- like to help others

- enjoy a good joke

- like to enjoy life and

- try to help others when they can.

The results of the research, according to Oetting and Donnermeyer (1998), show that a quality and structured implementation of leisure time prevents the appearance of behavioral disorders. The Youth Network of Croatia (Buković, 2010, according to Pehlić, 2014) conducted research on the problem, needs and social position of young people. Young people spend most of their leisure time in the private sphere, in the company of friends, watching television, staying online, listening to music. In the leisure time area, they are most affected by the lack of places where they can do things that rejoice them, and a large number of young people are unable to deal with hobbies due to lack of money and time. Kojadin and associates (2013, according to Pehlic, 2014) conducted a comparative study of youth needs related to their free time also in Croatia, and according to their results, young people are rarely included in organized forms of leisure time. The realization that leisure time takes place in a structured way, in terms of dealing with sports, positively influences the development of the prosocial behavior of young people. Such an understanding calls for the socialization of peers or members of the sports team. Peer education for young people is very important, approval and acceptance by peers influences the development of individual self-esteem, school success, participation in extra-curricular activities, moral development and social behavior. In the circle of peers, a circle of prosocial behavior is established - when a young person behaves prosocialy towards his/her peers, they return with such behavior (Pehlic, 2014). By observing the prosocial behavior displayed by team members, young athletes learn such behavior and will be more inclined to show it, especially if it is in some way stimulated. A strong point for such a claim is found in the research carried out by Mc Kenney (2001, according to Pehlic, 2014). In her work with young people who have a behavioral disorder, she applied a program to stimulate prosocial behavior based on learning observation. 
The program included an assessment of what behavior in adolescents needs to be changed, then planning the process of changing, applying and evaluating the planned activities. The program of prosocial behavior included: use of special maps that showed the steps in manifesting certain behavior, role-playing activities, and watching videos. The results of this program confirmed that in the context of sporting activities, young people can be taught prosocial behavior if there is an appropriate program and appropriate social-pedagogical support.

Many researchers have focused their interest in exploring the nature of the altruistic personality, as well as on investigating the traits that cause and encouraging an individual to help others in different situations (Eisenberg, 2002, according to Carlo, 2006). In one of the classic studies (Eisenberg et al., 2006), it was observed how ten thousand students are willing to help in different situations, including the student's willingness to donate money to an orphanage, to give presents to children who need it, etc. The researchers measured the extent of the altruistic personality of each student. Surprisingly, the extent to which students were prosocial in one situation (for example, giving a lot of gifts to children) was not highly linked to the prosocial behavior of that individual in another situation. The mean correlation between assisting in one and the other situation was only $r=.23$. The result shows that one cannot predict how much someone will be ready to help, although it is known how much the individual was willing to help in another situation. Furthermore, studies conducted among children and adults indicate that individuals with high results on the altruism scale are not as ready to help as those with average values (Batson, 1997).

These settings certainly point out that not only individual differences are important, but also some other factors. Therefore, when interpreting prosocial behavior, account must be taken of the situation determinants, the gender of the helpers, the culture in which they grew up, and the current mood of the person himself.

\section{CONCLUSION}

Prosocial behavior is growing with the development of thought and emotional processes and is determined by situational factors and the attitude of prosocial behavior. When analyzing the prosocial behavior of primary and high school students in terms of the structure of leisure time, statistically significant differences were found in a way that students with struc- tured leisure time performance compared to students whose leisure time is not structured. If we want to ensure that children and young people spend their leisure time in a socially positive way, it is necessary that leisure time includes activities that will relate to rest, personal development and rest. Accordingly, if the leisure time of children and young people were met with various socially acceptable activities, the greater would be the ability to adopt social skills such as the ability to build a good relationship, the ability to cooperate, the ability to manage conflicts and solve them. The population of children and youth actually forms its value system under various influences, i.e. under socialization agents, under the influence of family, school, friends, media, and the environment in which they spend their leisure time. The constructive use of leisure time for children and young people in a socially acceptable way is an indispensable problem that modern civilization should face if it seeks to focus on the development of a quality and meaningful life, and consequently, a comprehensive social action that would hinder negative ways of disposing leisure time for young people, as well as for directing their creativity in terms of proper social development.

\section{REFERENCES}

Achenbach, T., M., \& Rescorla, L., A. (2001). Manual for the ASEBA School-Age Forms and Profiles, Burlington, VT: University of Vermont, Research Center for Children, Youth and Families.

Badrić, M., Prskalo, I., \& Šilić, N. (2011). Razlike u strukturi slobodnog vremena između učenika urbanih i ruralnih područja. Poreč: 6. Kongres FIEP-a Europe. Zbornik radova - Tjelesna i zdravstvena kultura u 21. stoljeću - kompetencije učenika.

Batson, C.D.(1997). Self-other merging and the empathy-altruism hypothesis: Reply to Neuberg et al. Journal of Personality and Social Psychology, 73, 517-522.

Carlo, G. (2006). Care-based and altruistically-based morality. In M. Killen i J. G. Smetana (Eds.), Handbook of moral development (pp. 551-579). Mahwah, NJ: Lawrence Erlbaum Associates.

Eisenberg, N., Fabes, R. A., \& Spinrad, T. L. (2006). Prosocial development. In N. Eisenberg, W. Damon \& R. M. Lerner, Handbook of Child Psychology: Vol. 3. Social, Emotional, and Personality Development (pp. 646-718). New York: Wiley.

Ilišin, V. (2013). Mladi u vremenu krize. Zagreb: Institut za društvena istraživanja u Zagrebu i Friedrich Ebert Stiftung, Zagreb.

Marković, V., \& Arsić, S. (2005). Projekat: Provođenje organiziranog slobodnog vremena učenika osnovnih škola grada Pule. Pula: Savez izviđača Pule i „Smečko“ izviđačka agencija za organizaciju sportskih, vannastavnih i slobodnih aktivnosti djece i mladeži. 
Meščić - Blažević, Lj. (2007). Pedagoška prevencija poremećajau ponašanju adolescenata. Pula: Pedagogijska istraživanja, 4(2) 30-308.

Mlinarević, V. (2004). Stilovi slobodnog vremena srednjoskolaca Slavonije i Baranje. Pedagogijska istraživanja 1(2), $241-256$.

Mlinarević, V. (2007). Kultura slobodnog vremena srednjoškolaca. Napredak, 148 (1), 54-70.

Nola, D. (1990). Slobodno vrijeme - izraziti fenomen nove informatičke civilizacije. Zagreb: UID XXII, 5-6, 291296.

Oetting, E., R., \& Donnermeyer J., F. (1998). Primary socialization theory: the etiology of drug use and deviance. Substance Use and Misuse. 33(4), 995-1026.

Pedagoška enciklopedija II (1989). Beograd: Zavod za udžbenike i nastavna sredstva.
Pehlić, I. (2015). Mali broj mladih kvalitetno provodi slobodno vrijeme. http://novovrijeme.ba/izet-pehlic-mali-broj-mladih-kvalitetno-provodi-slobodno-vrijeme/(08.10.2017)

Pehlić, I. (2014). Slobodno vrijeme mladih - Sociopedagoške refleksije. Sarajevo: Centar za napredne studije CNS.

Raboteg-Šarić, Z. (1993). Psihologija altruizma: čuvstveni $i$ spoznajni aspekti prosocijalnog ponašanja. Zagreb: Alineja.

Tomić, R., \& Hasanović, I. (2007). Mladi i slobodno vrijeme. Tuzla: OFF-SET.

Žiga, J., Turčilo, L., Osmić, A., Bašić, S., Džananović Miraščija, N., Kapidžić, D., \& Brkić - Šmigoc, J. (2015). Studija o mladima u Bosni i Hercegovini. Sarajevo: Friedrich - Ebert -Stiftung (FES) 